\title{
Making Work-from-Home Work in the Public Sector: A Case Study of Mauritius
}

\author{
Ramesh Durbarry \\ Civil Service College, Mauritius, ATOM House, Port Louis, Mauritius \\ Email: durbarry.ramesh@gmail.com
}

How to cite this paper: Durbarry, $\mathrm{R}$ (2021). Making Work-from-Home Work in the Public Sector: A Case Study of Mauritius. Advances in Applied Sociology, 11, 357-376.

https://doi.org/10.4236/aasoci.2021.118033

Received: May 27, 2021

Accepted: August 7, 2021

Published: August 10, 2021

Copyright $\odot 2021$ by author(s) and Scientific Research Publishing Inc. This work is licensed under the Creative Commons Attribution-NonCommercial International License (CC BY-NC 4.0). http://creativecommons.org/licenses/by-nc/4.0/ (c) (i) (s) Open Access

\begin{abstract}
Work-from-Home (WFH) is not a new concept; however, its adoption in the public sector is rather slow. COVID-19 has forced us to find a new way of doing business, especially during the lockdown in many countries. WFH, or teleworking, as it is commonly known, has increased significantly with the advent of technology and improved communication. Its popularity is stronger in the private sector and less adopted in the public sector, mainly due to the traditional nature of the service that government delivers. This new pandemic has called for many governments to transform their way of conducting their operations using emerging technologies. This paper looks at the benefits and consequences of working from home. The study also looks at the conditions that would make working from home effective from the point of view of employees in the public sector. An online survey was conducted among public officers during the lockdown period to investigate their perceptions of working from home. The study found that public officers perceive the risk to catch the virus is the highest when travelling by bus and at their workplace. It is also found that the support from leaders does have an impact on employee productivity. Some pre-conditions to make work from home effective are highlighted in this study to guide managers.
\end{abstract}

\section{Keywords}

Work-from-Home, Transformation, Emerging Technologies, Leading WFH Employees

\section{Introduction}

On $12^{\text {th }}$ January 2020, the World Health Organisation (WHO) confirmed that a novel coronavirus (named COVID-19) was the cause of a respiratory illness in a cluster of people in Wuhan City in Hubei Province, China. This was reported to 
the WHO on 31 December 2019. The world's attention was drawn to observe the severity of the virus and measures were being taken, first to contain its spread and to start working on finding remedies. On 11 March 2020, the WHO declared the COVID-19 as a pandemic (a global sanitary crisis). As in many countries, the Government of the Republic of Mauritius reacted by setting up a High Level Committee chaired by the Prime Minister to take stock of the situation and of the impact of the virus on the various sectors of the economy.

On $18^{\text {th }}$ March 2020, Mauritius recorded three cases of COVID-19 and the Prime Minister took a firm decision that the country would be under sanitary lockdown for a period of two weeks. However, a total lockdown was subsequently imposed and further extended to the $1^{\text {st }}$ of June 2020. Only essentials services of the public sector, such as the health, police force and fire rescue services, were operating in the first instance. After the peaking of the pandemic in Mauritius, plans were put in place to prepare for resumption of some public services starting the $15^{\text {th }}$ of May until all public services are operational from the $2^{\text {nd }}$ of June 2020.

Resumption of activities in the public service had been planned in a staggered manner and social distancing for the safety of employees has been highly recommended. Decisions were also made to restrict the number of employees in any office set-up and to establish alternate days or extra shifts that reduce the total number of employees and customers in a facility at a given time.

Following the serious threat that the pandemic of COVID-19 is posing to human health, the Government of Mauritius agreed to the introduction of a Work-from-Home Scheme for public officers. Government sees it as an opportunity for Ministries and Departments to develop and implement the scheme for their staff on a pilot basis in the first instance. The benefits of the Work-from-Home Scheme were strongly underlined to encourage employees to adopt this new mode of working, such as: 1) continuity in the delivery of services, 2) spending lesser hours in traffic jams and reducing commuting costs, 3) improving work-life balance, 4) containing the spread of infectious disease (particularly COVID-19), 5) saving on fixed office costs, 6) a motivation for staff to work in an innovative environment with less stress and more job satisfaction, 7) improving their efficiency and effectiveness; and 8) giving more flexibility to organise tasks.

Although with these numerous many benefits, WFH mode of work also comes with some challenges and difficulties. A few pertinent questions remain with COVID-19 still around, such as, how safe do employees feel to get back to work? Where are the risks highest to be contaminated? How to work from home? What support are required from leaders, especially the type of leadership? How WFH is implemented in the public sector?

The paper is organised as follows. In the next section, a review of the literature on the definition of work-from-home, the benefits and challenges of working from home as well the impact WFH has on productivity are looked at. In Section 3, we discuss how the Government of Mauritius efficiently addressed the lockdown situation to ensure the safety of its citizens. Section 4 
reports the findings of a survey carried out on public officers on their perception of working from home during the lockdown period and section 5 provides some recommendations of how to make WFH work efficiently and Section 6 concludes.

\section{Literature Review}

\subsection{Definition of Work-from-Home}

There were calls for many years to introduce flexible working hours in the civil service since the 2008 Pay Research Bureau Report. The benefits for flexible hours were highlighted in the 2016 Pay Research bureau report for both the organisations and the employees. For the organisations, the advantages are: "improvement in productivity; reduction in absenteeism; less requirement for overtime as employees can manage busy and slack periods; completion of lengthy work assignments without resorting to overtime; potential for longer opening hours and public desk cover in the flexible periods including lunch time; and balance in family life and professional activities" (Pay Research Bureau, 2016). In the same report, the terms "Flexiplace" and "Homeworking" were further introduced. Flexiplace has been defined as "an arrangement whereby staff perform work in places other than the office" and Homeworking as "an arrangement involving people undertaking work primarily in their homes or who travel extensively but are primarily based at home" (paragraph 18.5.36).

The homeworking incentive was primarily targeting officers particularly at the professional level and above "for assignments that are project-based with verifiable performance indicators" (paragraph 18.5.37) upon approval from the Chief Executives of Ministries/Departments/Organisations.

The "home working" as stated in the PRB seems to be restricted to a certain grade level and its application has been limited. The Government has recognised the importance of working from home to increase productivity and has made provisions in the Workers' Rights Act whereby there is a legal provision for regulating the "work from home" framework through the Workers' Rights (Atypical Work) Regulations 2019. However, the said provision was restricted to primarily the private sector.

A commonly used term in the literature is teleworking. Teleworking can have different definition such as "telecommuting, networking, flexible working, working from home, remote working, home-based working, or mobile working” (Pearlson and Saunders, 2001). Telework, as explained by Fairweather (1999), enables employees to perform their work with the use of telecommunication technologies at their residence, which is the typical place. However, telework can also be practiced at alternate worksites (Meyers and Hearn, 2000), in which case, the worksite must be in proximity of their home to reduce the time spent in travelling (Dixon, 2003) and the employee must work at least one day per week (Scholefield and Peel, 2009).

Teleworking, as opposed to work-at-office, is the transition between being 
supervised and having face-to-face communication to being self-managed and communicating virtually (Kurland and Bailey, 1999). Telework can, therefore, be defined as "any form of substitution of information technologies for work-related travel" (Ellison, 1999).

Public organisations are currently facing a major challenge in how they can respond to the rapid changes in technology (Osborne and Brown, 2005). With advanced research and development in new technologies and the prevalence of COVID-19, there could be a new definition in work configuration. We are seeing emerging companies such as "Slack" and "Zoom" and well known multinationals like "Google" and "Microsoft", which are providing their e-tools for free with the hope that people will adopt their software as a new work tool even post the pandemic (Hern, 2020). On the downside, there is increasing pressure on internet service providers to familiarise themselves with new innovative technologies and for teleworking employees not to experience any issues concerning broadband connection and speed of connection.

In this period of COVID-19 pandemic, telework is being used as a measure to "flatten the curve" of the pandemic (BBC, 2020). In this case, telework can be considered as the "magic concept" as suggested by Pollitt and Hupe (2011). Such a measure is helping not only the organisation to continue its operation but to the economy at a large.

Another merit, as put by Barack Obama is that "attracting and retaining employees who are more productive and engaged through flexible workplace policies is not just good for business or for our economy-it's good for our families and our future" (The White House, 2010). In addition to improving work-life balance, working from home may reduce companies' rent costs and employee turnover and also benefit communities by lowering commuter congestion and emissions (Bloom, Liang, Roberts and Ying, 2014).

Other research studies have shown that teleworking can have a mixed effect on employees' quality of life, their productivity and stress level, their job commitment and job satisfaction, and the balance between the personal life and work (Handy and Mokhtarian, 1996). Since teleworkers have the ability to work at their own pace, they can spend more time with their families, hence improving their quality of life (Pearlson and Saunders, 2001). Ironically, Salomon and Salomon (1984) argue that teleworkers, who are not able to effectively manage their time between work and home, can suffer from unnecessary stress.

\subsection{Benefits and Consequences of Working-from-Home}

There has been a disruption from former traditional working practices. Companies are more willing to adopt new techniques such as working from home to remain competitive in the fierce and rapid changing business world. Many factors influence the increased in demand of teleworking and these include the advancement and ease of access to new technologies, changes in social trends, more women working which has given rise to dual income families, single-parent families, and the need to maintain work-family balance (Ellison, 1999). Kanel- 
lopoulos (2011) also brought into light that employees enjoyed a much better work-life balance while working from home.

Work-from-home is being encouraged as employees have the flexibility to choose where and when they can engage with their work, which helps to alleviate their travelling expenses (Kanellopoulos, 2011) and money spent on formal clothing (Riswadkar and Riswadkar, 2009). There are studies that have been conducted on the effect of time spent on travelling on work performance. Apgar (1998) and Dixon (2003) demonstrated that employees who worked from home dedicated more time in additional work as compared to those working from office. Baard and Thomas (2010) found that working from home could cause a reduction in the boundary between work and personal life. Mann and Holdsworth (2003) had noted that employees tend to work overtime, which can lead to severe health and mental issues.

However, Kanellopoulos (2011) found that employers benefited from WFH arrangement as it contributes towards less absenteeism of staff and lower turnover in terms of rents and utilities (Riswadkar and Riswadkar, 2009).

Pearlson and Saunders (2001) noted that employees working from home are autonomous compared to traditional employees. This is due to the fact that teleworkers can manage their time according to their working capacity. Selfmanagement and autonomy help employees to be more motivated and this leads to an increase in their level of job satisfaction (Kanellopoulos, 2011). However, Kurlan and Cooper (2002) brought up the issues and challenges faced by managers who were unable to efficiently supervise their employees.

Vega and Brennan (2000) found that autonomy has a negative impact on career prospects. Similarly, Bloom et al. (2014) found that workers working from home were less likely to be promoted than similar-performing peers working in the office, however, it significantly increased employees' productivity and job satisfaction.

Work from home has for some time grown over the years with the emergence of technologies and better connectivity. This has significantly increased during the COVID-19 pandemic, for example, in Germany the proportion of the workforce working from home has increased from $12 \%$ to $25 \%$, exceeding eight million people, stated the German labour minister, Hubertus Heil (cited in Dans, 2020). In the 1990s, however, despite the rapid growth in communication technology, the overall potential impacts of telework at a national level were not fully explored (Duarte and Snyder, 1999). This shift to work more from home could indicate the importance workers are placing on health concerns.

Briefly, the benefits to employees working from home are:

- In the present context, it reduces the risk to be contaminated;

- It provides a flexible work environment;

- It provides better work-life balance, hence improves the health state;

- It provides more time with family members;

- It reduces commuting time, hence, increases the time for other activities;

- It increases productivity and creativity; 
- It reduces stress;

- It increases job satisfaction. Some of the drawbacks are:

- No clear demarcation between work and personal life;

- Work time can become endless;

- Difficulty to socialise with co-workers;

- Requires good connectivity and equipment provisions;

- Rising electricity and connectivity costs, unless financed by the organisation;

- Micromanagement and constantly being monitored could lead to stress;

- Career prospect can be impacted negatively.

\subsection{The Debate on Productivity}

The immediate reaction from line managers to allow employees to work from home would be their concerns regarding productivity levels, especially in the public sector. The main issue is the measurement of productivity of employees in the delivery of public services. We cannot adopt the input-output measurement in the public service. It is more appropriate to measure productivity of a Ministry or Department rather than of an individual for the public sector. To the citizens, what matters most is the value that public service generates by using taxpayers money. Another measure is to use outcome as an indicator of productivity, however, as cited in Linna et al. (2010), Putnam (1993) rejects the idea of including outcomes in productivity measurement. He argues that to focus on outcomes includes changes which government has no control, for example, changes in health rather than patients treated or changes in the educational status.

According to Holzer and Seok-Hwan (2004), the concept of performance may represent a more attractive conceptual path toward improvement. Productivity and performance are functions of many factors-ranging from top management support, committed personnel at all levels, a performance measurement system, employee training, reward structures, community involvement and feedback to correction of budget-management decisions. It is thus important to build up capacities for productivity improvement (cited in Linna et al., 2010).

Although the Performance Management System (PMS) is in place in the Mauritian public sector, its effectiveness is yet to be measured. It becomes even more critical now to make the PMS functional and operative where key performance indicators (KPIs) are carefully thought of for each employee. Once employees understand their KPIs, along with their key results areas, measurement of work-from-home productivity will become clearer. However, performance will be judged on the effectiveness and efficiency as well as the quality of services delivered to the public.

According to a survey by Airtasker (2020), they found that working from home not only benefits employees by eliminating their daily commutes, it also increases productivity and leads to healthier lifestyles. On average, remote employees worked 1.4 more days every month, or 16.8 more days every year, than 
those who worked in an office. Moreover, on those workdays, they spent more time getting things done.

In a recent survey of professionals from age $18-74,54 \%$ of them found that working from home during the COVID-19 pandemic has had a positive effect on workers' productivity. The reasons for this, they said, were time saved from commuting (71\%), fewer distractions from co-workers (61\%) and fewer meetings (39\%) (Schrotenboer, 2020).

Conversely, another survey conducted by YouGov in partnership with USA TODAY and LinkedIn, researchers have found that problem solving and creativity suffer when workers are isolated from one another. Additionally, isolated work can lead to loneliness and boredom. Remote employees have also reported they worked more hours. For instance, in an online survey of 2001 adults from April 6-9, 25\% of respondents said working from home has had a negative impact on their productivity. The main reason cited was that it takes longer to get answers and information from co-workers. $43 \%$ of those working from home said they are communicating with their colleagues less than they did before. 31\% said their workload has decreased since they began working from home, while another $43 \%$ say their workload is unchanged. The rest (26\%) said that their workload has actually increased, with a lack of separation between home and work being cited by $31 \%$ of that group (The New York Times, 2020).

In Singapore, it was reported that those who had to travel long distances and who could perform most of the work at home opted to telework for only 1 - 3 days a week (Yap and Tng, 1990). In another study of how organisations perceived teleworking in Singapore, found about $12 \%$ of the respondents allowed their employees to telework while providing both formal and informal arrangements (Lam, Lim, and Loh, 1995). The main reason being that there was an increase in productivity along with reduced office space (cited in Bernardino, 1996). However, they found problems such as data security and inability to supervise employees.

\section{The COVID-19 Response by the Government of Mauritius}

The Government of the Republic of Mauritius has closely followed the evolution of the coronavirus (COVID-19) since the outbreak in Wuhan, China in January 2020. A series of actions and measures have been taken to prevent the spread of the virus in the Republic. For instance, since end of January 2020, all passengers travelling from China were screened at the airport through the thermal scanner. Similarly, passengers arriving by cruise ships were also screened. Passengers from China were closely monitored by the Public Health Inspectors, for a period of 14 days' post-arrival. A High Level Committee chaired by the Prime Minister was setup to take stock of the situation and of the impact of the novel coronavirus on the various sectors of the economy. By mid-February, all incoming passengers were screened manually and by means of thermal cameras. A sensitisation campaign was intensified on the virus by the Ministry of Health and Wellness. A soon as three cases of COVID-19 were detected, on 18 March the coun- 
try went into lockdown. The Government decided that the country would be under complete lock-down until 31 March 2020 with only essential services such as police, hospitals, dispensaries, private clinics, firefighters and banks being open. All other activities were banned during the curfew period. It was also decided that all supermarkets, shops and bakeries would also be closed until 31 March 2020. However, food distribution was organised for 35,000 households registered on the social register. Government decided that supermarkets, excluding bakeries, would restart operations as from 2 April 2020. Customers were allowed to enter supermarkets as per the alphabetical order of their names during specific days twice a week.

Since the economic sector was badly affected, Government provided a Wage Assistance Scheme to employees as well as Self-Employed Assistance Scheme to provide a basic level of income. Work Access Permits (WAPs) were allocated to allow movement of employees in specific sectors. An application was designed for employers to apply WAPs for their employees and was also accessible on the website besafemoris.mu. The App provides latest news along with measures to prevent the proliferation of coronavirus. Government has repeatedly requested citizens to consult the latest news on the application or the website for official updates instead of using social media platforms due to proliferation of fake news or inaccurate information. Heavy penalties were introduced for the dissemination of fake news on social media. The first lockdown ended on 31 May 2020 after no cases were reported. All activities resumed, with the exception of tourism. However, Government has allowed travellers, including tourists to enter the country provided they accept to be quarantined until the results for COVID-19 are negative. The travellers need to book their ticket together with the listed quarantine hotels at the time of travel through a dedicated website on the Mauritius Tourism Promotion Authority platform. A Premium Visa Travel Scheme was launched to attract long stay visit tourists.

\subsection{Activities in the Public Sector}

Although the country was in lockdown, many civil servants of the top management level were called on duty to ensure that certain essential services continue. However, even during the lockdown period, a staggered resumption for civil servants was implemented. For instance, as from 11 May 2020, all officers of the administrative cadre resumed duty to plan and implement the resumption of services of their respective Ministries/Departments. All Heads of Department/ Divisions/Technical unit also resumed work. All office auxiliary cadre, handy worker and similar grades resumed work to allow for thorough cleaning and sanitizing of office premises.

As from 15 May 2020 up 30\% capacity of remaining staff resumed work until 21 May 2020. As from 22 May 2020, a second batch of 30\% staff of Ministries/Departments resumed work to replace the first batch of employees who were working, and as from 2 June 2020, all staff of Ministries/Departments re- 
sumed duty.

During the lockdown, to enable public officers to commute from their residence to their workplace during the lockdown period, a Work Access Permit was issued. An App was designed to provide QR Code for the commuter. The Government has laid a lot of emphasis on the health and safety of its employees. Through a circular, practical actions were outlined regarding the cleanliness of premises, protective equipment, administrative arrangements, management of social distancing and personal hygiene.

To coordinate the resumption and to ensure the safety of employees, Ministries and Departments had set up a COVID-19 Dedicated Response Team. This response team had the task to take actions regarding the organisation of the workplace, ensuring that appropriate measures are taken for staff safety (such as social distancing), put in place facilities for interaction with the public, devise strategies to deliver public service, among others. The Ministry of Public Service, Administrative and Institutional Reforms had set up a Communication and Coordination Cell to attend to issues pertaining to the resumption of duty.

\subsection{Introduction of Work-from-Home Scheme in the Public Sector}

To restrict the number of officers in an office set up (to ensure social distancing) and also to have less commuters, Government has approved the Work-fromHome Scheme to be introduced in the public sector. The Scheme was introduced for an initial period of three months on a pilot basis. Under such a Scheme, the Supervising Officer and the employee mutually agree on certain deliverables. Indeed, with this change in the work environment due to the COVID-19 pandemic, the Workers' Right Act, 2019 (WRA) has been amended, more precisely, Section 17A where the employees are notified with a prior notice of at least 48 hours by the employer for working from home. Government is supporting the Scheme by providing some allowances to cover for internet access and phone costs. However, a fundamental question rest on the readiness of public sector employees to embark on the Work-from-Home mode.

It is in this context, a survey was conducted to assess the perception of public officers as well as state-owned enterprises on the new mode of teleworking, which the Government is encouraging to put in place.

Since the research was undertaken during the first lockdown period, an online survey was carried out and was deemed to be the most appropriate methodology to obtain responses. The online survey was carried out during the period 29 April 2020 to 7 May 2020 to employees of the public sector. Using the Cochran's formula to determine the minimum sample size resulted to 255 with $5 \%$ margin of error. Given the database of public officers held, the questionnaire was sent to 15,197 public officers from the civil service, parastatal organisations, local government and state-owned enterprises. A total of 3029 responses were received, representing a response rate of around $20 \%$. 


\section{Survey Results}

\subsection{Profile of Respondents}

Figure 1 depicts the responses received from the different organisation. The Civil Service represents $78 \%$ of responses received, followed by around $15 \%$ from parastatal organisations, 5\% from local government and the rest from State-Owned Enterprises.

In total, $63 \%$ of the respondents were female and $37 \%$ male. The distribution by age groups is illustrated in Figure 2 below with the majority between the age of 31 to 50 .

In terms of the grade of the employees, they were mostly from Supervisory grade (35\%) followed by Middle Management (31\%), Frontline Staff (26\%), Top Management (5\%) and the rest from Workmen/Manual grade.

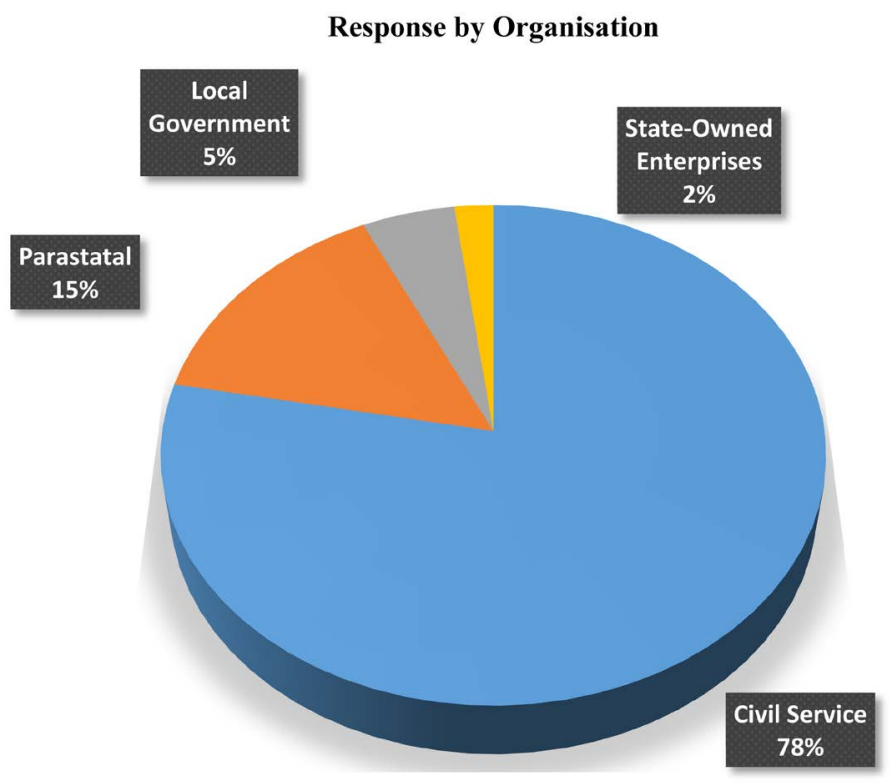

Figure 1. Response by organisation.

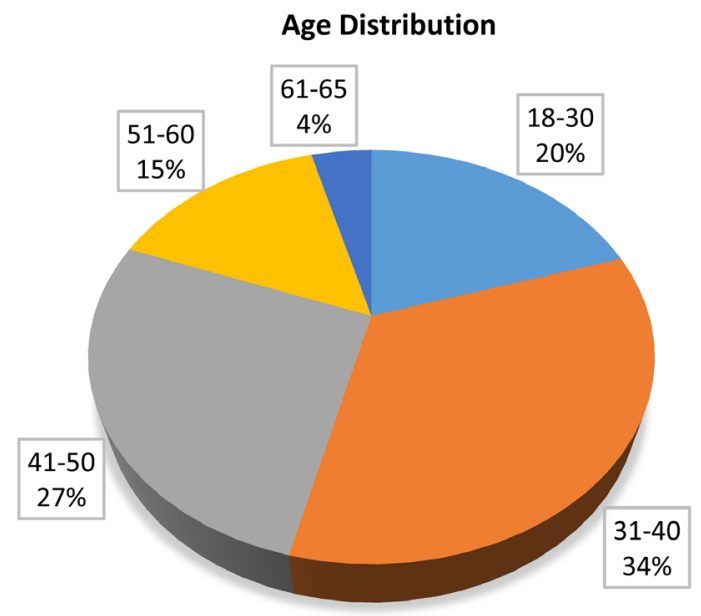

Figure 2. Age distribution. 


\subsection{Safeness to Go Back to Work}

During the lockdown period, there has been an ongoing awareness campaign on COVID-19 and precautions that must be taken by the public. The Government has, through the Ministry of Public Service, Administrative and Institutional Reforms, issued circulars to all Ministries and Departments on measures to be taken for the resumption to contain the virus, as explained earlier. Respondents were asked about their risk perception in resuming work after the lockdown period. Figure 3 illustrates that around $75 \%$ of respondents believed that it was not safe to get back to work after the lockdown. In fact, $49 \%$ of respondents perceived that the possibility of contamination still exists and is very high. About $27 \%$ of the respondents believed that people are not taking enough precautions.

\subsection{Where Does the Risk Lie?}

Respondents were asked where they think that the risk to catch the virus is the highest. As Figure 4 illustrates, more than one third of the respondents (37.4\%),

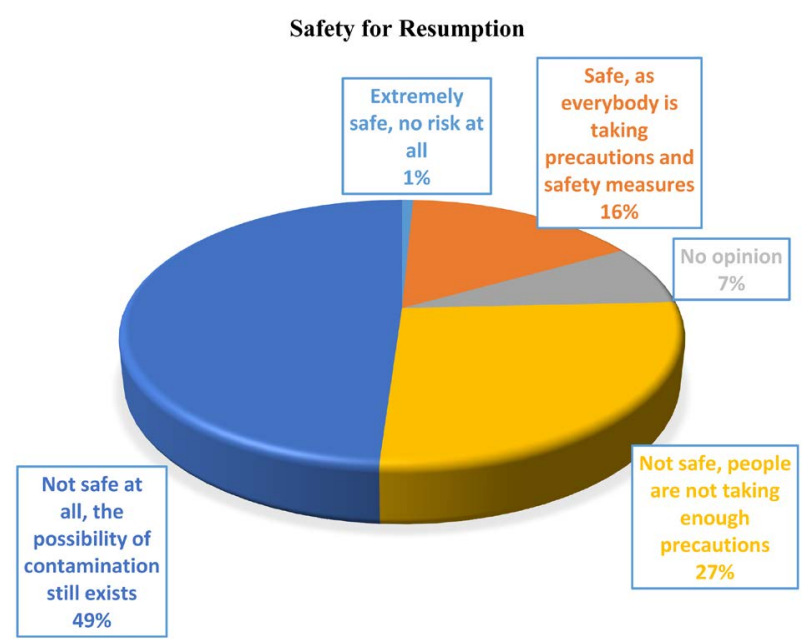

Figure 3. Safety for resumption.

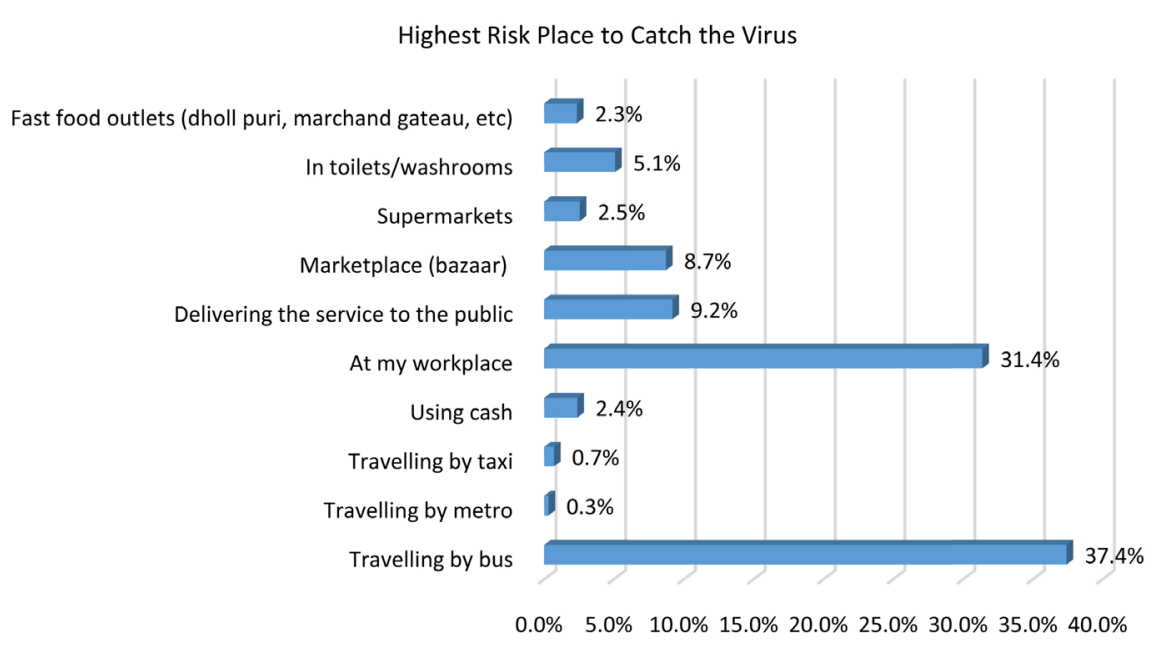

Figure 4. Highest risk place to catch the virus. 
believed that the risk to catch the virus is highest when travelling by bus. While a little less than one third of the respondents believed that the highest risk was at their workplace.

\subsection{Work-from-Home}

With the introduction of the Work-from-Home Scheme, as many as $68 \%$ of respondents are favourable to adopt the work-from-home mode of work, with $47 \%$ considering this option very favourably (see Figure 5 below). Of those who have responded highly favourable to work from home, the majority were female, $65 \%$ (representing $31 \%$ of the sample) and the $35 \%$ of male represented $16 \%$ of the sample. It was also observed that employees in the Supervisory grade constituted around $38 \%$ of those who are highly favourable to work from home. This was followed by $38 \%$ in the Middle Management grade.

\subsection{Barriers to Work from Home}

Working from home does come with some challenges as discussed in previous research studies in Section 2. Respondents were asked to name the three biggest challenges they perceive when working from home. Given the nature of work, especially in the civil service (since the majority of the respondents are from this category), many of the respondents, about $68 \%$, stated that accessing information to get their work done from home will be challenging (Figure 6). Around $47 \%$, indicated that lack of equipment such as a PC or laptop and internet connectivity would limit working from home and about $40 \%$ reported that collaborating with colleagues would be difficult. Around $26 \%$ of the respondents stated that they would struggle managing time to keep a regular schedule.

\subsection{Line Manager Communication with Employees}

Respondents were also asked as to how they would wish their line manager to contact them. It was found that more than $50 \%$ of them are open for their line

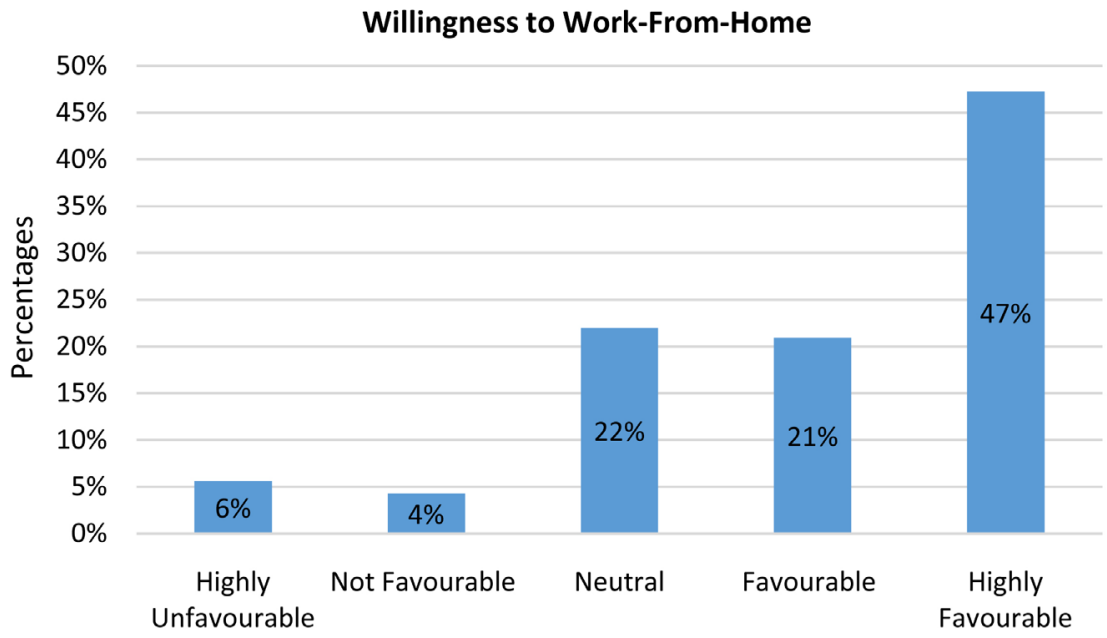

Figure 5. Willingness to work-from-home. 


\section{Barriers to Work from Home}

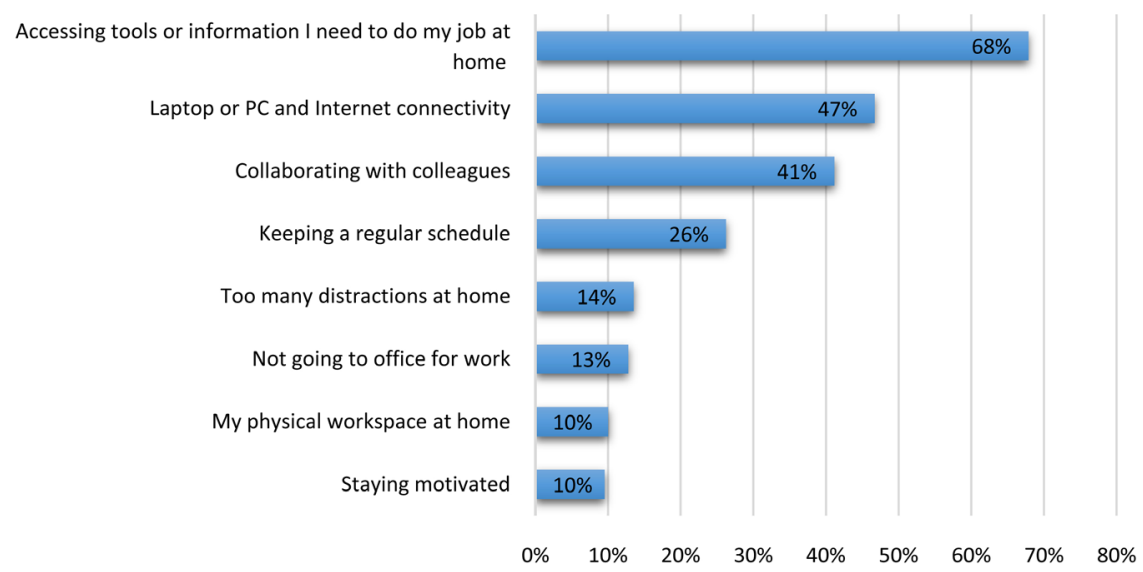

Figure 6. Barriers to work-from-home.

manager to contact them by phone anytime during the day. Around $21 \%$ of them are open for their line manager to contact them by phone at any time. However, $21 \%$ equally wished to be contacted by email only. Only $11 \%$ of them would like to be contacted via video conferencing as illustrated in Figure 7.

\subsection{Leadership Traits: Support from Line Managers}

Leading employees remotely may be challenging as found in the literature from previous studies. In this context, respondents were asked what would be their two biggest support that they would require from their line manager. Figure 8 illustrates those types of support requested from employees. Fifty four percent (54\%) of respondents requested that they must be explained clearly what are the expectations from the tasks that would be allocated. Fifty percent (50\%) of the total respondents would like to receive well-defined tasks. This is not surprising in the public sector, given that the Work-from-Home Scheme clearly mentions that Supervising Officers should agree in advance on tasks to be performed by members of their team together with delivery outcomes as agreed upon. Records should be kept of all tasks performed/hours put in by officers concerned and endorsed by the Head of Section. Around 30\% of the respondents would like their line manager to be available for discussions and around 25 percent would like to receive feedback on their completed tasks.

\section{Recommendations to Increase Productivity by Working-from-Home}

Based on the findings of the study, and also from the literature review, working from home can have many challenges in terms of productivity and managing self. There are certain measures and actions that can be taken that might relieve these difficulties. Below are step-by-step suggestions to improve the effectiveness of working from home, whether in the civil service or private sector:

\section{1) Clarify Tasks}




\section{Mode of Contact by Line Manager}

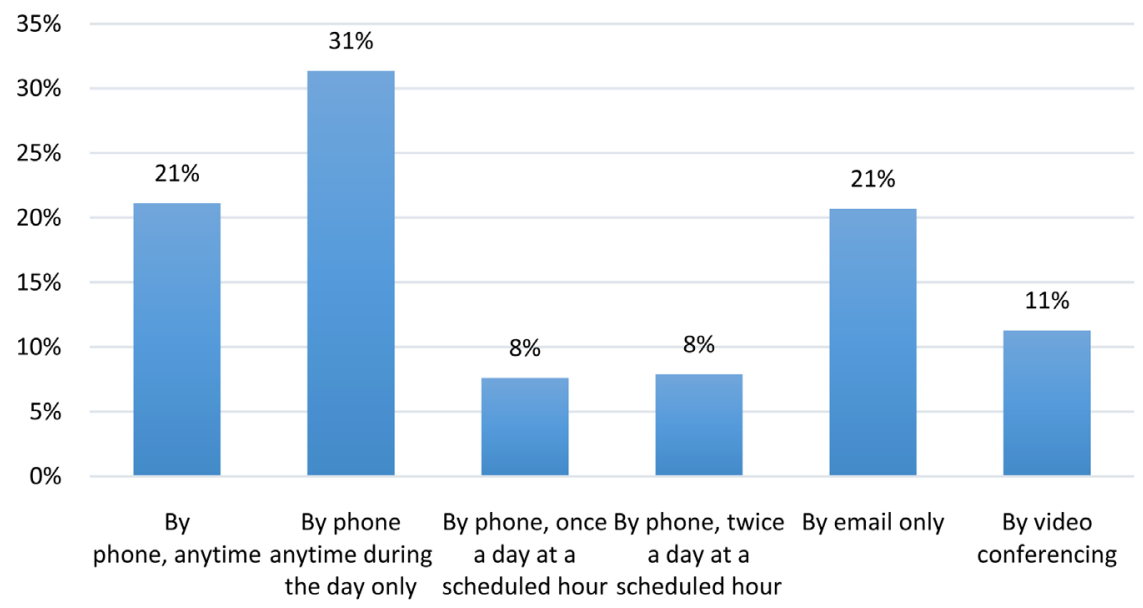

Figure 7. Mode of contact by line manager.

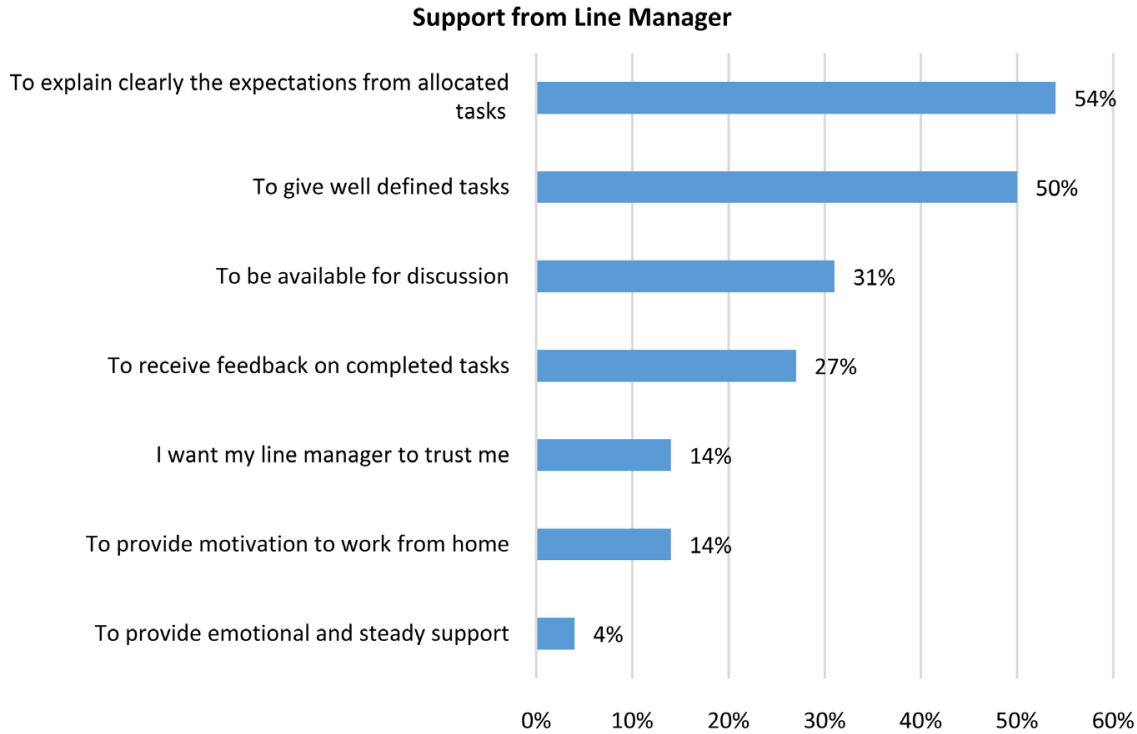

Figure 8. Support from line manager.

From the survey, many respondents have voiced out that they would like to have clarifications of tasks that their line manager allocates. When engaging on a Work-from-Home mode, especially in the civil service where duties are strictly adhered to the scheme of duties, difficulties arise when allocating tasks. This is perhaps why a performance appraisal with defined goals and key performance indicators would help to conduct work within set boundaries. An employee, therefore, needs to get clarifications which tasks will be performed at home. Once the tasks are mutually agreed between the employee and the line manager, the former will be better prepared to achieve the deliverables within an agreed time frame. This will provide certain flexibility in planning and time management.

\section{2) Create a Working Space}

Once an agreement has been reached to work from home, there needs to be 
some changes for a smooth transition from a supervised-office environment to a self-managed working space. Our normal habit to work is to operate in a defined office set up. Apart from a basic office desk and a chair, the workstation is normally structured in such a way that we can easily identify our papers, equipment, stationeries, files etc. A routine is developed everyday as soon as one reaches the office from switching on the PC or laptop and picking up from the previous day.

Working from home will require a certain physical adaptation. First of all, try to create a dedicated space at home. This will have the benefit of keeping oneself focused in an organised area. Organise the dedicated area to make it effective for working. Try to get basic supplies (phone, pen, notepad, etc.) within reach, otherwise time be wasted looking for these when needed. Keep the area clean and tidy. Make it an "official” workspace.

\section{3) Request for Support}

To work from home requires necessary software and hardware equipment as well as internet access. You will need to discuss these facilities prior to accepting of working from home. The Government of Mauritius, for instance, under the Work-from-Home Scheme, provides cell phone and internet allowances to public officers.

\section{4) Understanding from Family and Disturbances}

Expect to be disturbed by sound of ringing phone, kids and family members calling you anytime while you are at work. Pets around the house and temptations to play games on phone or laptop can make you lose focus. It is recommended that you make your family members understand that you are working and not to be disturbed or make noises. In this way, the rules are well set for all parties.

\section{5) Groom Properly}

When working at home, there is a tendency to dress up very informally, such as, staying in pyjama outfit the whole day, having scruffy hair, and so on. Working from home should not be dress-code free. Proper attire and grooming will, first, facilitate the transition from a "sleepy mood" to a "working mood". Second, it gives a moral boost and builds self-confidence. Third, one can attend video conference calls at any time.

\section{6) Schedule Working Time}

Working at home can be an endless activity. Often employees are caught up into their work assignments that they are unable to demarcate the boundaries between work and personal time. This consequently disturbs the whole work-life balance. It is advisable to spend, at the most, the same amount of time that one would spend at the office. In this sense, one would stick to a daily routine without comprising family or time for self. In our survey, it was found that 1 in 4 respondents would find it difficult to keep a regular schedule when working at home. This may seem challenging, however, use alarms to let know when you should start working and when to stop. Use unused commuting time to carry household chores and other activities.

\section{7) Take Breaks}


There is a time to work and a time to look after oneself as well as the whole family, otherwise it can lead to stress and work-family conflicts (Greenhaus and Powell, 2003). Teleworkers should avoid making the laptop a bed partner as this may disturb the sleeping and waking up time patterns. With work from home, more time is available to spare in comparison to the time that one spends from getting dressed up to the amount of time one would spend in commuting toand-back from the office. Use those time "savings" judiciously. Start by drafting a schedule to include the time that will be spent on work, having tea and lunch breaks and a time to get some fresh air. The most challenging part is to stick to the schedule. Use calendar apps with notifications or email to schedule those slots in.

\section{8) Communicating with the Line Manager}

Keep a communication line on the progress of the allocated tasks with the line manager. Depending on the line manager's way of assessing an employee's work-from-home productivity, the employee is recommended to send regular updates on the tasks s/he is carrying out. It is best to arrange for a specific time during the day to communicate with the line manager to do so. Staying in touch with the line manager develops a better professional relationship. One can use phone, video conferencing or emails. When using emails, use proper grammar to avoid any misunderstandings to ensure that the message is well understood. Re-read the email content before sending, if necessary.

\section{9) Communication with Colleagues}

As many as $40 \%$ of the respondents in the survey believed that keeping in touch with colleagues will be a struggle while working from home. Isolation may start creeping in when working from home all the time. During break time, staying in touch with colleagues, who may be are either working from home themselves or are at the office, will keep one abreast of developments in the organisation. It is then unlikely to miss out on important decisions that have been taken. Staying in touch with friends and colleagues will avoid the feeling of loneliness from being suddenly cut off from people one is used to see every day. Take some time to socialise with friends and colleagues. Arrange for a chat time if possible with colleagues and friends. This will increase productivity and to get away from boredom.

\section{0) Avoid Distractions}

Being free at home, where no one is "observing", might tempt the teleworker to engage in non-productive activities such as watching TV, playing games, browsing the social media and so on. To stay focus on the tasks, try to remove all games and apps from the laptop and phone. Family members or pets might disturb the flow of work. In such a case, try to organise and explain family members of the importance to complete certain tasks and specify a time of availability. Sticking with the time schedule will keep certain focus and increase productivity.

\section{1) Looking after own health}

Around $10 \%$ of respondents revealed that working from home might indulge them in "eating too much". As mentioned earlier, getting enough sleep and 
waking up as on a normal day of work will keep one healthy and active. Doing some exercises and going outside to get some fresh air at times will boost up productivity.

\section{Conclusion}

COVID-19 has disturbed the way we are working. A new normal has emerged and has reconfigured, and is transforming, the operations in organisations. With Governments putting a high emphasis on the health of their citizens, by taking strict measures such as lockdown, full resumption of traditional public services is challenging. New ways to deliver public service are being sought of and technology is playing a much bigger role. This implies a change in the way employees perform their tasks. Teleworking has started to emerge as a serious option in the public sector, which was once mostly adopted by the private sector. Since the conditions of work in the public sector are highly regulated, a workfrom-home scheme will necessarily be designed to obtain the desired outcome. It has to be pointed out that without access to technology working from home will be ineffective. Its success will depend on hardware and software provided, but equally the quality of output from working from home will largely depend on the type of tasks that can be performed, self-management, time management, communication with colleague and line managers, and the adaptation pace to a new culture of work.

Another pre-condition for the success of increasing the productivity of working from home is the leadership style of our leaders. The skills and qualities of leaders will define the accomplishment of an organisation-an effective communicator, a good listener, being honest, inspiring, compassionate, empathetic and sympathetic are some of the traits of great leaders.

A new era in this digital age has begun for the public sector to embrace emerging technologies such as Artificial Intelligence (AI) and Internet of Things (IoT) to better improve public service delivery and the lives of citizens. However, the major obstacle will be the availability and sharing of data to enable efficient use of technologies. Concurrently, there is a high need to build capacities and institutions, such as the Civil Service College, Mauritius has a major role to play. Innovation will reconfigure the way services will be delivered and how work will be performed. Employees should no more be confined to an office setting only.

Whether work from home will be successfully embedded in the public sector remains to be seen. Once the initial three months pilot project of working from home is over, the College will conduct another survey to assess its effectiveness.

If work-from-home becomes an effective and efficient mode of work and if we explore the full potentials of available technology, then the next step for public officers will be to move from "Work-from-Home" to "Work-fromAnywhere". 


\section{Conflicts of Interest}

The author declares no conflicts of interest regarding the publication of this paper.

\section{References}

Airtasker (2020). The Benefits of Working from Home, Comparing the Productivity, Spending and Health of Remote vs. In-Office Employees. https://www.airtasker.com/blog/the-benefits-of-working-from-home

Apgar, B. Y. (1998). The Alternative Workplace: Changing Where and How People Work. Harvard Business Review, 76, 121-136.

Baard, N., \& Thomas, A. (2010). Teleworking in South Africa: Employee Benefits and Challenges. SA Journal of Human Resource Management, 8, 1-18.

https://doi.org/10.4102/sajhrm.v8i1.298

BBC (2020).

https://www.bbc.com/worklife/article/20200312-coronavirus-covid-19-update-work-fr om-home-in-a-pandemic

Bernardino, A. T. (1996). Telecommuting: Modeling the Employer's and the Employee's Decision-Making Process. Garland Publishing.

Bloom, N., Liang, J., Roberts, J., \& Ying, Z. J. (2014). Does Working from Home Work? Evidence from a Chinese Experiment. The Quarterly Journal of Economics, 130, 165-218. https://doi.org/10.1093/qje/qju032

Dans, E. (2020). Working from Home: It's Time to Have the Conversation about What's Really Involved. Forbes.

https://www.forbes.com/sites/enriquedans/2020/05/10/working-from-home-its-time-to -have-the-conversation-about-whats-reallyinvolved/\#e6859bb74c5c

Dixon (2003). Telecommuting: Issues in Public and Private Sector Employment. Queensland Parliamentary Library.

Duarte, D. L., \& Snyder, N. T. (1999). Mastering Virtual Teams. Jossey-Bass.

Ellison, N. B. (1999). Social Impacts: New Perspectives on Telework. Social Science Computer Review, 17, 338-356. https://doi.org/10.1177/089443939901700308

Fairweather, N. B. (1999). Surveillance in Employment: The Case of Teleworking. Journal of Business Ethics, 22, 39-49. https://doi.org/10.1023/A:1006104017646

Greenhaus, J. H., \& Powell, G. N. (2003). When Work and Family Collide: Deciding between Competing Role Demands. Organizational Behavior and Human Decision Processes, 90, 291-303. https://doi.org/10.1016/S0749-5978(02)00519-8

Handy, S. L., \& Mokhtarian, P. L. (1996). The Future of Telecommuting. Futures, 28, 227-240. https://doi.org/10.1016/0016-3287(96)00003-1

Hern, A. (2020). Covid-19 Could Cause Permanent Shift towards Home Working. The Guardian.

https://www.theguardian.com/technology/2020/mar/13/covid-19-could-cause-perman ent-shift-towards-home-working

Holzer, M., \& Seok-Hwan, L. (2004). Mastering Public Productivity and Performance Improvement from a Productive Management Perspective. In M. Holzer, \& L. Seok-Hwan (Eds.), Public Productivity Handbook (2nd ed., pp. 1-17). Marcel Dekker.

Kanellopoulos, D. N. (2011). How Can Teleworking Be Pro-Poor? Journal of Enterprise Information Management, 24, 8-29. https://doi.org/10.1108/17410391111097401 
Kurlan, N. B., \& Cooper, C. (2002). Manager Control and Employee Isolation in Telecommuting Environments. Journal of High Technology Management Research, 13, 107-126. https://doi.org/10.1016/S1047-8310(01)00051-7

Kurland, N. B., \& Bailey, D. E. (1999). Telework: The Advantages and Challenges of Working Here, There, Anywhere, and Anytime. Organizational Dynamics, 28, 53-67. https://doi.org/10.1016/S0090-2616(00)80016-9

Lam, S. H., Lim, G. S., \& Loh, C. M. (1995). A Survey of the Status of Information Systems, Singapore. Proceedings of the 1995 Pan-Pacific Conference on Information Systems, Singapore, 200-204.

Linna, P., Pekkola, S., Ukko, J., \& Helinä, M. (2010). Defining and Measuring Productivity in the Public Sector: Managerial Perceptions. International Journal of Public Sector Management, 23, 479-499. https://doi.org/10.1108/09513551011058493

Mann, S., \& Holdsworth, L. (2003). The Psychological Impact of Teleworking: Stress, Emotions and Health. New Technology, Work and Employment, 18, 196-211. https://doi.org/10.1111/1468-005X.00121

Meyers, N., \& Hearn, G. (2000). Communication and Control: Case Studies in Australian Telecommuting. Australian Journal of Communication, 27, 39-64.

Osborne, S. P., \& Brown, K. (2005). Managing Change and Innovation in Public Service Organisations. Routledge.

Pay Research Bureau (2016). https://prb.govmu.org/Pages/default.aspx

Pearlson, K., \& Saunders, C. (2001). There's No Place like Home: Managing Telecommuting Paradoxes. The Academy of Management Executive, 15, 117-128. https://doi.org/10.5465/ame.2001.4615008

Pollitt, C., \& Hupe, P. (2011). Talking about Government: The Role of Magic Concepts. Public Management Review, 13, 641-658. https://doi.org/10.1080/14719037.2010.532963

Putnam, R. D. (1993). Making Democracy Work: Civic Traditions in Modern Italy. Princeton University Press. https://doi.org/10.2307/j.ctt7s8r7

Riswadkar, A., \& Riswadkar, A. V. (2009). Balancing the Risks of Remote Working: Walking the Telecommuting Line. The John Liner Review, 23, 1-5.

Salomon, I., \& Salomon, M. (1984). Telecommuting: The Employees' Perspective. Technological Forecasting and Social Change, 25, 15-28. https://doi.org/10.1016/0040-1625(84)90077-5

Scholefield, G., \& Peel, S. (2009). Managers' Attitudes to Teleworking. New Zealand Journal of Employment Relations, 34, 1-13.

Schrotenboer, B. (2020). Working at Home Had a Positive Effect on Productivity during the Pandemic, Survey Says. USA TODAY.

https://www.usatoday.com/story/money/2020/05/04/coronavirus-pandemic-might-ga me-changer-working-home/3061862001

The New York Times (2020). What If You Don't Want to Go Back to the Office? https://www.nytimes.com/2020/05/05/business/pandemic-work-from-home-coronavir us.html

The White House (2010). Statement by the President on National Work and Family Month.

https://obamawhitehouse.archives.gov/the-press-office/2010/10/25/statement-presiden t-national-work-and-family-month

Vega, G., \& Brennan, L. (2000). Isolation and Technology: The Human Disconnect. Journal of Organizational Change Management, 13, 468-481. 
https://doi.org/10.1108/09534810010377435

Yap, C. S., \& Tng, H. (1990). Factors Associated with Attitudes towards Teleworking. Information and Management, 19, 227-235.

https://doi.org/10.1016/0378-7206(90)90032-D 